\title{
A Study on the Self Esteem and Academic Performance among the Students
}

\author{
Laveena D’Mello ${ }^{1}$, Meena Monteiro ${ }^{2}$, and Nelson Pinto ${ }^{3}$ \\ ${ }^{1}$ Assistant Professor, College of Social Work, Srinivas University, Mangalore, Karnataka, \\ India \\ ${ }^{2}$ Associate Professor, MSW Department, School of Social Work, Roshni Nilaya, Mangalore, \\ Karnataka, India \\ ${ }^{3}$ Research scholar, Department of Sociology, Mangalore University, Karnataka, India \\ E-mail: lavynoronha@gmail.com
}

Type of the Paper: Medical Case Study.

Type of Review: Peer Reviewed.

Indexed In: OpenAIRE.

DOI: http://dx.doi.org/10.5281/zenodo.1156448.

\section{Google Scholar Citation: IJHSP}

\section{How to Cite this Paper:}

D’Mello Laveena., Monteiro Meena, \& Pinto Nelson. (2018). A Study on the Self Esteem and Academic Performance among the Students. International Journal of Health Sciences and Pharmacy (IJHSP), 2(1), 1-7.

DOI: http://dx.doi.org/10.5281/zenodo.1156448.

International Journal of Health Sciences and Pharmacy (IJHSP)

A Refereed International Journal of Srinivas University, India.

(C) With Authors.

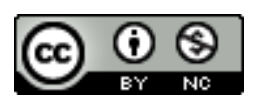

This work is licensed under a Creative Commons Attribution-Non Commercial 4.0 International License subject to proper citation to the publication source of the work.

Disclaimer: The scholarly papers as reviewed and published by the Srinivas Publications (S.P.), India are the views and opinions of their respective authors and are not the views or opinions of the SP. The SP disclaims of any harm or loss caused due to the published content to any party. 


\title{
A Study on the Self Esteem and Academic Performance among the Students
}

\author{
Laveena D’Mello ${ }^{1}$, Meena Monteiro ${ }^{2}$, and Nelson Pinto ${ }^{3}$ \\ ${ }^{1}$ Assistant Professor, College of Social Work, Srinivas University, Mangalore, Karnataka, \\ India \\ ${ }^{2}$ Associate Professor, MSW Department, School of Social Work, Roshni Nilaya, Mangalore, \\ Karnataka, India \\ ${ }^{3}$ Research scholar, Department of Sociology, Mangalore University, Karnataka, India \\ E-mail: lavynoronha@gmail.com
}

\begin{abstract}
The purpose of self-esteem is to feel and imagine that people nurtured in their mind over time about their self. In simple words, self-esteem is self-assessment; this perception and evaluation can be positive or negative and pleasant or unpleasant. Children with high selfesteem, usually feel good about themselves and better able to resolve their conflicts with other children and are resistant to deal with problems. One of the most important human traits to achieve objectives is self-esteem. The term self-esteem means "reverence for self". The "self" pertains to the values, beliefs, and attitudes that we hold about ourselves. Having a strong will and self-confidence, decision-making power and originality, creativity, sanity and mental health is directly related to self-esteem and sense of self-worth. It also refers to an individual's sense of his or her value or worth, or the extent to which a person values, approves of, appreciates, prizes, or likes him or herself. During childhood, if individual's feelings are respected, thoughts valued and abilities recognized then self-esteem strengthens. When feelings are trampled upon, thoughts belittled and ability criticized then the individual's self-esteem remains at a low point of development and is therefore weak. During the course of time, an individual faces many life situations. Depending upon the success or failure and one's reaction to every significant situation in life, self-esteem grows stronger or gets considerably weakened Self-esteem is described as the evaluation that one makes about oneself, based on one's self-worth. Increases and decreases in self-esteem generally bring strong emotional reactions. Self-esteem and academic performance are interrelated factors. This study tries to bring the connectivity between academic performance and the self-esteem. The main aim of the study is to know the level of self-esteem of the students with low academic performance. The objectives of this study are to investigate the relationship between self-esteem and academic achievement, to understand the Socio-Economic background, to assess the level of self-esteem, and to know what could be the reason for low academic performance in spite of having high self-esteem. The research design used for the study would be descriptive in nature.
\end{abstract}

Keywords: Self-esteem, Academic performance, Students, Development, Attitude.

\section{INTRODUCTION :}

Satisfaction of one need creates another need that commands the person's attention and efforts. The basic assumption in Maslow's theory is that the lower order pre-potent needs must be relatively satisfied before the person can become aware of or motivated by higher order needs. Physiological needs should be satisfied first followed by safety and Security needs, love and belonging needs. Self-esteem needs are fourth in the hierarchy. Maslow divided it into self-respect and respect for 
others. To Maslow, a satisfaction of selfesteem needs generates feelings and attitudes of self-confidence, self-worth, capacity and the feeling of being useful and necessary in the world. The frustration of these needs leads to feelings and attitudes of inferiority, ineptness, Weakness, passivity, and dependency. These negative self-perceptions give rise to basic discouragements, a sense of futility and hopelessness in dealing with life's demands and low evaluation of self vis-à-vis others. In summary, it has been established from the numerous readings that high self-esteem correlates highly with self-reported happiness which may arise from a feeling of competence, confidence, goal-directedness, and selfefficacy which may lead to scoring well in exams [1-3].

Self-esteem is a widely used concept both in popular language and in psychology. The foundation of self-esteem is; The practice of living consciously, The practice of selfacceptance, The practice of self-responsibility, The practice of self-assertiveness, The practice of living purposefully, The practice of personal integrity (Branden,1994) [2]. Maslow's Theory of needs, Carl Rogers Theory of personal development and Bednar and Peterson's Theory of self-esteem have all contributed to the need and importance of high self esteem. The theory of Maslow's hierarchy of needs investigates the effects of self-esteem on academic performance. According to Maslow people need to be motivated to seek personal goals that make their lives rewarding and meaningful. The law contends that human beings have wanted and rarely reach a state of complete satisfaction. He stated that all human beings have needs that are innate and are systematically arranged in ascending (order) hierarchy of priority.

\section{LOW ACADEMIC PERFORMANCE :}

Low academic performance can be defined as a failure of an individual to execute his/her duties diligently so as to meet the specified standard. Apart from inadequate training, there are various other factors that contribute to poor performance. Such additional factors can be classified into two types. The first type includes factor involving student's characteristics such as motivation, inadequate personality, poor health condition and lack of self-confidence. Lack of motivation results in inadequate performance since the student's morals lowered by the working condition. The instance a college has under staff is likely to have many fails in exams. This may be due to the fact that the existing staffs are overworking unable to attend to all students. Another factor causing inadequate performance is the poor health conditions of the students. It influences mental state of a student. Along with this the absenteeism and lack of teaching experience in the field also effect on the children. There are several factors such as Student-born problems, Learning Process Problems, Societal-born problems, Assessment problems, and Administrative problems. In most cases these factors contribute largely to the poor performance are; Understanding of the subject matter by the students, The method of teaching, Evaluation method, and the regularity of the students to the Class. Teachers too want to cover so many pages/topics /courses within a short period of time. Ask them at the end of the day they will not be to make anything out of it, meanwhile, they have been seeing to be studying all day long [4-5]. There are two groups of students differ due to their different abilities to focus attention in class, or their different abilities in remembering information, or their different abilities in solving problems or involve in making decisions. It was understood that the potential relationship between students who differ in their levels of academic performance in terms of their personality and their mental or cognitive processes. The excellence in academic life demands a high level of intelligence. But, in addition to intelligence, other factors that can be useful predictors of academic performance are personality, behavior and mental characteristics. Along with this, the mental activities that the students use in receiving information, comprehending it, storing it, retrieving it and using it to make decisions and solve problems is necessary [6].

(1) LOW SELF ESTEEM

Self-esteem as being the sum of an individual's successes divided by what they think they ought to achieve. The Principles of Psychology Self-esteem can be increased by achieving great successes and maintained by avoiding failures. Self-esteem was therefore defined as being competence-oriented but also 
open to change. Alexander (2001) [7-8], the founder of the Self-Esteem Network in Britain, views self-esteem as a syndrome, as a set of indicators for mental well-being. The core of self-esteem is an "unconditional appreciation of oneself" meaning an appreciation of both an individual's positive and negative potential in its fullest sense [9-10]. Alexander also distinguishes between 'trait' self-esteem which reflects confidence or ability in a particular area, such as work or port, and 'global' selfesteem which is intrinsic worthiness regardless of what particular abilities or qualities an individual may possess. Cooper Smith (1967, 1981) in this study [11], suggested four major factors which are important in the development of self-esteem: The treatment and acceptance received from significant others in life, A person's past successes, The values and aspirations which modify and interpret a person's experiences and How a person responds to devaluation. Erickson (1959) [12] specifically identified academic achievement as a vital component in forming a healthy selfimage [13].

(2) ACADEMIC PERFORMANCE AND SELF ESTEEM

Academic self-esteem is operationally defined as the evaluative appraisal of the experience of being capable of meeting academic challenges and being worthy of happiness. Self-esteem and academic performance are important for the holistic development of the students. The investigator personally is interested to work with teenagers and had come across some children who are finding difficult in academic performance due to problems like the comparison between the siblings and too much expectation from the parents. So the researcher felt that this study will help in the better understanding of low academic performers and in the future to plan out some programmes for such adolescents. The scope of the present study in the fact that it aims to explore selfesteem level among the adolescents which will result in high achievement or vice versa is the study aim. The researcher felt that it is good to find out in which area these children are good at and what the factors that contributes to enhancing their self-esteem and the reasons for the poor performance in the academic. Because as the researcher has observed and seen these children with poor academic performance are good in extracurricular activities like drawing, dancing and playing. These features motivated the researcher to undertake this present study [14-15].

\section{METHODOLOGY :}

This study is descriptive in nature. It aims at studying the level of self-esteem of the students with low academic performance. And the objectives are; to understand the SocioEconomic background of Respondents, to assess the level of self-esteem of the Respondents, to assess the co-relation between Self- Esteem and Academic Performance and to assess the Gender differences in the level of Self- Esteem and Academic Performance. Total 50 students from Government Schools have taken. The students (aged 13-15) studying in a High school in the district Dakshina Kannada and have achieved low marks (below 60\%) and failed in one or more subjects would be the population for the present study. The sample selected from 2 private schools (25 each). The Simple Random sampling techniques of probability sampling has been used to draw out the sample. The samples are selected from the population which include an equal number of boys and girls.

Tools of data collection: The Researcher has concentrated on collecting primary data by questionnaire methods. Keeping in mind the observation as a supportive tool while meeting them and seeing their progress reports. The secondary data has been obtained from the books, magazines, reports, school records, and websites.

\section{MAJOR FINDINGS :}

Socio-Demographic profile: It consists of participants personal details. The main purpose of this profile is to obtain personal and familial information of the subjects. The profile contains items such as name, date of birth, religion, language, educational status of the parents, the type of family, number of siblings and the family. As far as Socio-Demographic Profile of the Respondents is a concern, there are an equal number of male and female 25 male and 25 female and the total sample was 50 in number. The age of the respondents, among the total respondents more than half the size 58\% belongs to the age group of $14-15$ years and remaining $42 \%$ are of 13 years of 
age. As far as their place of residence, the majority of $70 \%$ of the respondents live in the urban area and remaining 30\% are from the rural area. And the size of the family is $60 \%$ of the respondents' families have 4-7 members and $40 \%$ of the respondent's family members are less than 4 in number. Majority $74 \%$ of the respondent's parents have completed their high schooling which means these children are from educated family. The respondent's religion is a concern, vast majority of $58 \%$ of the respondents belong to Christian families and remaining $32 \%$ are from Hindu family and $10 \%$ are from Muslim family.

Economic Condition: Regarding Economic Condition, the occupation of the father and occupation of the mother, more than half that is $60 \%$ of mothers are homemakers and remaining $40 \%$ are working mothers, who are involved in private, government sector and self-employment. Regarding the occupation of the father, $86 \%$ of them are indulged in the government sector and in lower cedars, which includes Police, Teachers, Engineers, and Security Guards, working in the Public sectors of lower cedars. $14 \%$ of the fathers are working away from home like other parts of the state including Gulf countries. 36\% of the total respondent's parent's monthly income is below 10,000 Rupees, $48 \%$ of the respondent's parent's monthly income is between Rupees 10,000 to 20,000 , and remining $16 \%$ of the respondent's parent's monthly income is more than Rupees 20,000.

Parent's income impact on self-esteem via academic performance: Three major components of the income of the parents, selfesteem and academic performance are interrelated. Social class and the income have a direct relationship. The income is related to status in the society, the way of life and the cultural level. All these depend on slandered, the more you have income the high is the slandered and the vice versa. Attitude regarding education is related to the income. Parent's level of learning along with income is determined an influence on children's education. Some studies say, motivation to studies, depends more on the parents' level of learning than on their level of income. Other studies indicated that the most influential family components on performance are not socio-cultural or economic, but rather those pertaining to the effective or psychological dimensions: that is, although good academic preparation is provided by the parent, and a positive cultural environment, favour scholastic performance, it is the effective and rational variables which stands out the most as factors that contribute to better performance. There is no significant relationship between the two variables. So the above studies contradict my study and also there is no significant correlation between Self Esteem and Academic Achievement of the students in the present study.

Academic performance and self esteem: Majority $50 \%$ of the respondents does have high self esteem, 26 percent have moderate level of self esteem and remaining $24 \%$ have low self esteem. The high self esteem is more among children and those children are very good in performance and participation in various school activities like competitions, sports, extracurricular activities etc. They also mingle very well with their friends, all other school children meet and talk to the teacher and they do not have hesitation to meet the Headmaster/ Headmistress in the school. The study says that $76 \%$ of the students have more self esteem but they are poor in their academic performance. So the hypotheses there is a significant correlation between Self Esteem and Academic Achievement of the students do not correlate in the present study. There are other reasons which may affect the respondent's low academic performance.

\section{CONCLUSION :}

The conclusion is drawn from the major findings of the study where the researcher found that there is a gender difference where the female respondents have more self-esteem than male respondents. But there is no significant correlation between the self-esteem and academic performance of the respondents. Besides, the educational system of the country, the child's psychological environment-their family, peers, teachers are of utmost importance in determining the adolescent's performance at school/college. While the college's influence on the adolescent's performance, has been acknowledged, almost all the studies and practical experiences substantiate the fact that parents, friends and significant people can make a world of 
difference to an adolescents life, in academic performance and personality.

\section{SUGGESTIONS :}

- Intervention programme for ParentsTeachers to help the adolescence to increase their self-esteem and academic performance. An effective intervention practice can be organized to help the adolescence to improve their self-esteem and academic performance

- Students who do not excel or who do not show outstanding academic performance should not be left aside. Rather the people who are directly and indirectly involved in their academic life; namely lecturers/teachers, family members, peers, and counsellor should be providing help to this group of students.

- Poor academic performance might be yielded because of poor teaching, due to a gap between materials used to teach and evaluation instruments especially those used for international purposes. These gaps have to be bridged.

- Students need to give attention effectively, organize information thorough comprehension and perform expressions effectively (e.g., reading books, writing papers etc.). Thus effective cognitive functioning is critical for all students to learn and profit from their educational experiences.

- The adequate preparation here should be the amount of concentration body, spirit and soul put into the study-hour. In other words, it is a matter of our mindset. We need to apply our minds to our studies while preparing for examinations, which are a function of commitment, seriousness, and concentration.

- Further research studies could have possible and much more effective and reveal if there was a much larger population that was studied over a much longer period of time. A comparative study on urban and rural sample would give an understanding of the difference in the two population and also Government and private schools/colleges.

\section{REFERENCES :}

[1] Baumeister, Roy F., Campbell, J.D.,
Krueger, J.I., and Vohs, K.D. (2005). Exploding the Self-Esteem Myth. Scientific American, US.

[2] Branden N. (1994). Six Pillars of SelfEsteem. Bantan Books, New York.

[3] Hill, S.E. \& Buss, D.M. (2006). The Evolution of Self-Esteem. In Michael Kernis, (Ed.), Self Esteem: Issues and Answers: A Sourcebook of Current Perspectives. Psychology Press, New York. 328-333.

[4] D’Mello Laveena, Govindaraju B. (2016). Implication of Academic Stress in Adolescents. International Journal of Scientific Research and Modern Education (IJSRME), 1 (1). 302-327.

[5] D’Mello Laveena, Govindaraju B. Meena Monteiro (2016). A Study on the Challenges Faced by Single Parent on Teenager Care. International Journal of Advanced Trends in Engineering and Technology (IJATET), 1 (1). 54-59.

[6] D’Mello Laveena, Meena Monteiro (2017). A Study on the Challenges of Government Primary School Teacher in Dakshina Kannada District. International Journal of Case Studies in Business, IT and Education (IJCSBE), 1(2), 44-51, DOI: http://dx.doi.org/10.5281/zeno do.1004676.

[7] Alexander, F.M. (2001) The use of the Self. Amazon publication, ISBN10: $0752843915 \quad$ ISBN-13: 9780752843919.

[8] James, W. (1890). The principles of psychology (Vol. 1). New York: Holt.

[9] Burke C. (2008). Self-esteem: Why? Why not?. Homiletic and Pastoral Review, New York.

[10] Gaylin, N. L. (1996). The self, the family, and Psychotherapy. The Person-Centered Journal, 3, 31-43.

[11] Stanley Coopersmith (1967, 1981). The antecedents of self-esteem. Psychologists Press, Palo Alto, CA

[12] Erikson, E. H., Paul, I. H., Heider, F., \& Gardner, R. W. (1959). Psychological issues International Universities Press, 
(Vol. 1).

[13] Rogers, C. R., \& Dymond, R. F. (Eds.). (1954). Psychotherapy and personality change. University of Chicago Press, Chicago.

[14] Rosenberg, M. (1979). Conceiving the Self. Basic Books, New York.

[15] Rosenberg, Morris, and R. G. Simmons. (1972). Black and White Self-Esteem: The Urban School Child. American Sociological Association, Washington. 